\title{
Village-Based Institutional Development Strategy to Prevent the Paddy-Field Conversion at Pandeglang Regency, Banten, Indonesia
}

\author{
Phd, Lala M. Kolopaking \\ Director of Center for Agriculture and Rural Development Studies, Bogor Agricultural University \\ Prof. Yonny Koesmaryono
}

Vice Rector of Academic and Students Affairs, Bogor Agricultural University

\begin{abstract}
Indonesia government needs innovative policies preventing the paddy-field conversion in the current era of regional decentralization. Average of paddy-field conversion in Indonesia has reached 187,200 hectares per year. Irrigated-paddy-field in Indonesia that converted to non-agricultural purpose in 2009 had already reached 3.09 million hectares (42.4 percent). The highest conversion areas were in Java and Bali islands that reached 1.67 million hectares. The study in Pandeglang Regency has shown the prior strategy to prevent paddy-field conversion. It requires the integration the protection toward the peasant based on inter- village participatory partnership to develop the rural area. The developed institution should follow the current applicable regulation, namely the Local Public Service Agency or Badan Layanan Umum Daerah (BLUD) to protect the paddy-fields. It does not only by managing logistic to support the production of the peasants, but also as a synchronizer among multi-parties for the empowerment actions of the peasants to manage the paddy-field farming. The government should use various development approach policies to prevent paddy-field conversion. Top-down development and bottom-up approach is required to be affirmed. Moreover, technocratic approach should be supported by participatory development. Otherwise, the stakeholders should be involved to implement the ruralbased institutional development strategy preventing the paddy-field conversion.
\end{abstract}

Keywords: paddy-field conversion, inter-village partnership, empowerment, peasantry institution, rural- based strategy.

\section{Introduction}

Paddy-field conversion in Indonesia has become one of the threats against the rice production. Several studies showed that government's efforts to prevent the paddy-field conversion haven't been effective yet (Nyak et al., 2003; Irawan, 2005; Dinda et al., 2015). BPS (2003) reported the average of paddy-field conversion in Indonesia has reached 187,000 hectares per year. According to BPS (2009) database, the number of irrigated paddy-field which has been scheduled to be converted for non-agriculture purpose reached at 3.09 million hectares (42.4 percent) and the highest extent was in Java and Bali islands that reached 1.67 million hectares. The cause of paddy-field conversion in Java and Bali is different than what has mattered outside, such as the island of Sumatera, Sulawesi, Kalimantan and Papua. Paddy-field conversion in Java and Bali were mostly caused by regional development due to the extension of industries and properties (Wahyunto et al., 2004). Meanwhile outside Java, paddy-field conversions have been occurring due to the palm-oil expansion. It is recorded, that the average palm oil plantation extension was on the highest number $(7.67 \%)$ in 2004-2014 per year, then reached a peak at 10.95 million hectares in 2014 (Directorate General of Plantation-Ministry of Agriculture, 2014). Kedi and Nana (2011) argued that the paddy-field management policy is required to underlie with the decentralization policy, particularly with land management in the authority of regional government.

In 2014, Indonesian government had released two new regulations revising the legal foundation of decentralization policy. There are Law No. 23 of 2014 on Local Government and Law No. 6 of 2014 on Village. Based on that issue, the interesting point is to find out the new institutional form for the prevention of paddy-field conversion. It considered with the implementation of both laws. Yet, that the paddy-fields issue was already recognized having a relation with the dynamic of peasantry life in the village. Should be noted, those that able to be addressed with the peasant and land issues are Law No.41 of 2009 on protection of sustainable food farm-lands and Law No.19 of 2003 on protection and empowerment of the peasantry. 
In line with the problems above, this study conducted at Pandeglang Regency in Banten Province. Pandeglang is the largest number of paddy-field area ( 54,080 hectares) in Banten province. Paddy-field area in this regency consists of 22,044 hectares of irrigated-paddy-field (40.8\%) and 32.036 hectares of non-irrigated paddy-field (59.2\%). This regency was selected because of the threat of land conversion. It occurred due to economic development in Pandeglang which intended to switch from agricultural based toward tourism sector. This process has attracted investors to develop supporting facilities and infrastructures of tourism such as hotels, restaurants and transportation which included airport and highways. Besides that, Pandeglang Regency has been striving to arrange a regulation over the prevention of paddy- field conversion.

Regional economic change is related to the transformation of peasant community in Pandeglang Regency. In 2013, proportion of peasant household still relatively high, about $66 \%$ of 283,486 households. Most of the peasant farmers on three areas are relatively old (82.4\%), which dominated by $45-70$ years of age. Meanwhile, the youth are either working on non-agricultural sector or migrating into urban area to get occupation with the higher income. Xie et al. (2005) reported that migration of peasant households toward urban area - working on industry sector - could threaten the sustainability of agriculture, especially the existence of paddy-fields. Kolopaking (2000) noted that the village migrant labors do not only go to urban area to work, even they could become international migrant labors in Asia Pacific and Middle East countries. Bernard et al. (2014) mentioned that prevention of land conversion is not merely about land aspect (physical), but also related to other problems that associated with the peasants, including lack of capital access, knowledge and technology, and limitation of land (access to natural resource).

Agrarian reform studies in Indonesia indicated the regional governments programs are ineffective due to the process which tending to marginalize the access to control the paddy-fields and impoverish the peasants (Erizal et al., 2002; Syahyuti, 2011). Therefore, formulating the strategy to prevent the paddy-field conversion by strengthening the village-based development capacity of the peasants became important to protect and empower them. Fuer (2008) argued that keeping the existence of paddy-field should be shielded by sustainable agricultural development policy from the local government which constructed by the reformist initiatives with the new mindset from the stakeholders. By considering this condition, this study aimed to formulate the institutional village-based development strategy in the pursuit of preventing paddy- field conversion by the peasants, and at the same time could improve their welfare.

\section{METHODOLOGICAL FRAMEWORK}

This paper is a policy study, with two main objectives: (1) formulating the goal settings of the policy, and (2) finding a direction of the institutional development process. These two steps are interrelated between one and another. To formulate the policy, it involves analytical and synthetic approach on system thinking framework (Allen, 1978; Eriyatno, 2010). Controlling land conversion rate is a goal setting of this researched policy. Thus, analyzing the condition and capacity the peasants and the paddy-field management institution are two inseparable issues. This study also addresses the issue of paddy-field management stabilizing the utilization of the resource and achieving sustainability of the resource use at the regional (regency) level.

However, it is assumed that paddy-field farming management has been implementing by using traditional method i.e., involving family members as farm labor and own management of the resources. This situation implies that paddy-field farming management has not already supported by a strong organization. Thus there was not a certain planning yet to guarantee the sustainable farming for the peasant family (Arnold, 2005). In addition, the market of the products tends to grow out of their control, thus the peasants have a lack of bargaining position. This has neglected the peasants' ability as a subject to manage their paddy-fields since still represented themselves as the owner, rather than as the subject who has a capability in managing their farms sustainably.

The first step of this research began with identification and verification of the paddy-field area by conducting re-mapping analysis. This process used ethic approach by using indicators based on researcher's point of view to back up the result of re-mapping analysis. Data collection was conducted by implementing a survey to 180 peasants by utilizing a structured questionnaire. Result of this stage had became as the analytical tools to analyze the political ecology of structure and trends of paddy-fields area. The second step was used emic approach, which placing the researcher and the subject as applied in qualitative approach (Moleong, 1991). Data collection included the following steps: 1) Field observation; 2) Conducting in-depth interview; and 3) Conducting Focus Group Discussion involving stakeholders and expert at the regional level. The purpose of this stage was analyzed the policy about the peasant as a subject of paddy-fields management by villageaffirmation based. This analysis was conducted to find a new development business formulation into institution to upgrade 
the peasant capacity. It is also implemented to raise the bargaining position in the system of paddy-field management that is viewed in the context of regional development policy. Most of peasantry still represented that of paddy-field land use as a food land. It caused by the opinion that the area and community engagement as determinant factor able to develop paddy-field area unless with advanced cultivation and well-organized institution. According to Kolopaking (2008), paddyfields management is related to management institutional cooperation between the villages in the rural area.

The next stage is formulating the institutional development rural-based strategy to prevent the paddy-field conversion. It used SWOT (Strength, Weakness, Opportunity and Threat) analysis. SWOT matrix that applied to determine the specific purpose is controlling the rate of paddy-field conversion by protection and rural-based empowerment of the peasant. Therefore, identification of internals and externals factor was conducted. Other than that, usage of SWOT matrix was used to exploring the strategies as much as possible to prevent the paddy-field conversion by empowering the peasant in the future unlimitedly on particular constrains (Bidhendi, 2005).

The last stage is to formulate the decision stage by determining the best strategy. It used Analytic Hierarchy Process (AHP)SWOT analysis. Kahraman (2007) argued that AHP is needed due to some weaknesses on SWOT such as its rather indicating qualitative result if it is quantified thus there is no clear point/rate between the factors that appears on its SWOT components. Likewise on the rate between the factors at each of components, it is important to make priority point so that the determination of strategy with the merging of AHP-SWOT analysis will much easier to be selected. AHP-SWOT is also used to determine the proper factor, sub-factor, actors, purpose and priority strategy in the protection towards paddy- field from land conversion by rural-based protection and also empowerment of the peasant in the region level (units of regency). By AHP, the best strategy will be gained from entire strategies that already appeared and recommended from SWOT matrix. AHP-SWOT is a kind of theory that applying quantitative measurement (quantifiable) and or intangible criteria. Decision making has conducted with multi-criteria approach by pair wise comparison method which appears from preferred scale among the sets of alternatives (Saaty, 1991).

By this Second Step, the forms of institutional affirmation (community) and the village (in the context of government) has formulated to order to cooperate with the "external actors". Defined that involving multi-actors, family affirmation process and rural institution on the level of group or rural community will able to manage their paddy-field as a sustainable area and continued by institutional cooperation development between the villages.

\section{THE DATA}

This research was conducted from May to November 2015 (6 months period). Re-mapping process was conducted to build up the result from verification team based on data analysis from : (a) Satellite imagery from Ministry of Agriculture, Republic of Indonesia year 2010; (b) Satellite imagery from Google Earth, (c) Paddy-fields map which interpreted from Ministry of Agriculture, Republic of Indonesia year 2010, (d) Land-Use Planning Map, Data Of Trade Business License in Pandeglang Regency, (e) Irrigation Map, Roadway Map, and Rivers Map from Pandeglang Regency, (f) Slope Map, Soil Map and Rain Fall Map, (g) Village Potential Statistics/ PODES (number of residents, number of peasants, existing land use), and (h) Local Regulation of 2015 on Protection of Sustainable Agricultural and in Pandeglang Regency. This survey was conducted to gain information about social economy situation based on the result of regional re-mapping analysis, by using purposive sampling in 6 districts in Pandeglang Regency as follows: Sumur, Cimanggu District, Sindang Resmi District, Cikeusik District, Panimbang District and Cimanuk District. Another result data are manuscripts from in-depth interview with the peasant from each representative village and result from FGD (Focus Group Discussion) with the peasants that facilitated by the experts, and also expert meeting which involves official governments from Pandeglang Regency.

\section{RESULTS AND DISCUSSION}

Based on the result from Re-mapping the paddy-field process, it has categorized two kinds status of Unconvertible Land. The first category is Permanent Unconvertible Land is the agricultural land that not allowed to used/ converted to be used as non-agricultural purpose and Conditional Convertible Land which able to be converted with certain condition/ prerequisites for public purpose such as highway buffers (province and regency), railways, highways, or the airports. From Table 1 shows The First Category (A) and Second Category (B) which derived from two optional Scenarios that can be implemented by the local government. First Scenario, the extent of the sustainable paddy-field that already stated on the local regulation at 53.000 hectares has adjusted to $43,650.4$ hectares. While on the Second Scenario was adjusted to $37,627.6$ hectares. Distinction of both scenarios is caused by the change of paddy-field extent on the Second Scenario 
which has decreased at 23 districts from 35 districts $(66 \%)$. Those excluded lands are will be purposed for regional economy development as non-agriculture paddy-field-area. The paddy-field area categories for each scenario are described on Table 1.

Table 1. Paddy-field Area Category Based on Land Conversion Scenario By District (2015)

\begin{tabular}{|c|c|c|c|c|c|c|}
\hline \multirow[t]{2}{*}{ District } & \multicolumn{2}{|c|}{ First Scenario } & \multirow[t]{2}{*}{ Total } & \multicolumn{2}{|c|}{ Second Scenario } & \multirow[t]{2}{*}{ Total } \\
\hline & Category $\mathrm{A}$ & Category B & & Category $A$ & Category B & \\
\hline Angsana* & 1490,1 & 853,1 & 2343,2 & 1738,7 & 0 & 1738,7 \\
\hline Banjar* & 267,9 & 92,9 & 360,8 & 315,7 & 0 & 315,7 \\
\hline Bojong* & 636,7 & 61,7 & 698,4 & 657 & 0 & 657 \\
\hline Cadasari* & 385,6 & 60,5 & 446,1 & 476,4 & 32,5 & 508,9 \\
\hline Carita & 50,1 & 806,9 & 857 & 84,9 & 772,1 & 857 \\
\hline Cibaliung & 271,8 & 38,8 & 310,6 & 310,7 & 0 & 310,7 \\
\hline Cibitung & 495,7 & 233,9 & 729,6 & 566,8 & 197,2 & 764 \\
\hline Cigeulis & 906,2 & 177,4 & 1083,6 & 1058,1 & 0 & 1058,1 \\
\hline Cikedal & 655,9 & 299,4 & 955,3 & 727,9 & 0 & 727,9 \\
\hline Cikeusik* & 4250,5 & 631,9 & 4882,4 & 4786,1 & 106 & 4892,1 \\
\hline Cimanggu* & 554 & 959,2 & 1513,2 & 617,1 & 1036,9 & 1654 \\
\hline Cimanuk* & 786,7 & 606,3 & 1393 & 1392,9 & 0 & 1392,9 \\
\hline Cipeucang* & $195,^{3}$ & 414,4 & 609,8 & 332,2 & 0 & 332,2 \\
\hline Cisata* & 548,2 & 58,3 & 606,5 & 585 & 0 & 585 \\
\hline Jiput $^{\star}$ & 578,1 & 445 & 1023,1 & 953,2 & 69,2 & 1022,4 \\
\hline Kaduhejo* & 830,5 & 560,9 & 1391,4 & 1364 & 26,1 & 1390,1 \\
\hline KarangTanjung* & 0,9 & 96,1 & 97 & 3,1 & 15,8 & 18,9 \\
\hline Koroncong & 241,2 & 112,3 & 353,5 & 305,8 & 0,2 & 306 \\
\hline Labuan & 37,7 & 290,6 & 328,3 & 68,4 & 0 & 68,4 \\
\hline Majasari & 228,5 & 259,9 & 488,4 & 327,5 & 25,5 & 353 \\
\hline Mandalawangi* & $705,^{3}$ & 963,4 & 1668,8 & 1091,8 & 577,1 & 1668,9 \\
\hline Mekarjaya* & 90 & 76,1 & 166,1 & 117,1 & 13,8 & 130,9 \\
\hline Menes* & 426,9 & 87,1 & 514 & 514,4 & 0 & 514,4 \\
\hline Munjul* & 924,1 & 169,5 & 1093,6 & 1093,6 & 0 & 1093,6 \\
\hline Pagelaran* & 1729,2 & 291 & 2020,2 & 1897,8 & 0 & 1897,8 \\
\hline Pandeglang* & 94,9 & 380,5 & 475,4 & 134,5 & 0 & 134,5 \\
\hline Panimbang* & 279,5 & 1270,8 & 1550,3 & 292,5 & 13,3 & 305,8 \\
\hline Patia* & $1972,{ }^{3}$ & 285,4 & 2257,8 & 2256 & 0 & 2256 \\
\hline Picung & 1968,3 & 300,1 & 2268,4 & 2214,8 & 0 & 2214,8 \\
\hline Pulosari* & 456,5 & 108,9 & 565,4 & 559,8 & 4,5 & 564,3 \\
\hline Saketi & $278,^{3}$ & 344 & 622,4 & 306,1 & 0 & 306,1 \\
\hline Sindangresmi* & 1896,5 & 175,8 & 2072,3 & 2019,8 & 0 & 2019,8 \\
\hline Sobang* & 831,9 & 2167,5 & 2999,4 & 965,4 & 0 & 965,4 \\
\hline Sukaresmi* & 2260,3 & 423,5 & 2683,8 & 2347,2 & 6,2 & 2353,4 \\
\hline Sumur & 719,6 & 455,3 & 1174,9 & 852,9 & 320,7 & 1173,6 \\
\hline TNUK & 190,5 & 855,9 & 1046,4 & 264,5 & 810,8 & 1075,3 \\
\hline Total & 28236,1 & 15414,3 & 43650,4 & 33599,7 & 4027,9 & 37627,6 \\
\hline
\end{tabular}

Based on the expert meeting, there were two different parties with different purpose. In one side, the first party agreed to conserve the paddy-field but on the other side, the second party tended to convert the paddy-field to accelerate economic development in Pandeglang Regency. However, according to the workshop and expert meeting result, it has finally concluded that the selected option was The First Scenario (Table 1). The First Scenario consisted of Permanent Unconvertible Land category (A) at 28,236.1 hectares and Conditional Convertible Land (B) at 43,650.4 hectares. It has chosen by the reason of the uncertainness of development plan implementation on the paddy-field area that will be converted in several districts. It's mean that the peasant on those districts will not derive any agricultural service programs from government Regency. Moreover, the peasant will much easier to be manipulated selling their land with a low price to the "land speculator". This situation obviously harms the peasant livelihood and their family.

Based on Focus Group Discussion involving the Public Official and House Of Representatives of Pandeglang Regency and NGO, it was concluded that Paddy-Field on the First Scenario Management was divided on Three Areas. Area I, Area II, Area III (Table 2 and Fig 1). Basic notion of area division for Paddy Field Area Management (Table 2.) is paddy-field area 
on the selected districts. It will be converted which manageable to be controlled preventing the paddy-field conversion. Characteristic of those areas are the more we look up at Area I toward Area III, the larger area of paddy-field will relatively going to be converted. There are Area I (30.5\%), Area II (37.3\%) and Area III (40.4\%). Hence, paddy land management in districts of Area I and II needs to be focused on the increasing of peasant income from rural industry of paddy-field productivity. This way, it is expected that the peasant will be protected and empowered to prevent the paddy-field conversion. While in the Area III, instead conducting such actions, the important issue is developing other enterprises. It is related to the enhancement of peasant's income as the impact when the paddy-field conversion policy is implemented.

Comply the peasant's perceptions on the three paddy-field management areas, paddy-field conversion is determined by intensity of paddy-field use as a productive land. It goes hand in hand with the low of the rice farming productivity in Indonesia in recent times due to the lack of water sufficiency caused of the channel irrigation, fertilizer problem and pest and plant diseases control (Susanti et al., 2015; Carambas et al., 2015). Paddy-field use has several differences between the peasant from each Area (Fig 2). Based on peasant's opinion, cropping pattern of cultivation paddy-paddy-fallow (bera) (44 \% of 180 peasants) is applied during a year. Most of the peasant in Area I and II are apply it. Besides that, other cropping pattern of cultivation is paddy-paddy-paddy system (64.6\%) which applied in Area III.

The peasant in Area III (93.3 \%) also claimed that paddy-field cultivation able to fulfill the living needs for their household. While the proportion of peasant in Area I (66.1\%) and II and (21.3\%) in this case were lower than Area III. Due to the intensity of paddy field use that smaller on both areas, the peasants are likely selling their paddy-land to others so that the higher prevention of paddy-field conversion will take place in the village. Besides that, most of the peasant are elderly (88.2 $\%$ ) and have a low education background (73.3\% from Primary school). Yet, the youth of peasant's family member are tend to migrate outside the village seeking a higher income. Moreover, the low proportion of peasant's opinions were found in Area I (46.7 \%) and Area II (33.3\%) who are expects and orients their children becoming as a peasant in the future. Being as paddy-field peasant is no longer as a preferred occupation. It caused of such occupation is not pledges an adequate income. Hence, preventing the paddy-field conversion needs to accommodate the protection and empowerment of the peasant. Hence, those actions are expected to raise their income to reach more suitable life.

Table 2. Paddy-field Area Management in Pandeglang Regency

\begin{tabular}{|c|c|c|c|c|}
\hline \multirow{2}{*}{$\begin{array}{l}\text { Area } \\
\text { Area I }\end{array}$} & \multirow{2}{*}{$\begin{array}{l}\text { District } \\
\\
\text { Angsana*, Munjul }^{*}, \text { Pagelaran*, Panimbang*, } \\
\text { Patia*}^{*} \text { Picung, Sindangresmi*, Sobang*, } \\
\text { Sukaresmi*, Cibaliung* }\end{array}$} & \multicolumn{2}{|c|}{$\begin{array}{l}\text { Paddy Field Area (Hectares) } \\
\text { Category }\end{array}$} & \multirow{2}{*}{$\begin{array}{l}\text { Total } \\
19,599.6\end{array}$} \\
\hline & & $\begin{array}{l}\text { A } \\
13,624.1\end{array}$ & $\begin{array}{l}\mathrm{B} \\
5,975.5\end{array}$ & \\
\hline $\begin{array}{l}\text { Paddy field area (\%) } \\
\text { in Area I }\end{array}$ & & 69.5 & 30.5 & 100 \\
\hline Area II & 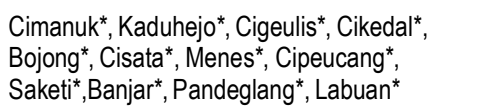 & $5,665.4$ & $3,373.5$ & $9,038.9$ \\
\hline $\begin{array}{l}\text { Paddy field area (\%) } \\
\text { in Area II }\end{array}$ & & 62.7 & 37.3 & 100 \\
\hline Area III & $\begin{array}{l}\text { Mandalawangi, Jiput, Carita, Pulosari, } \\
\text { Cadasari, Majasari, Koroncong, Mekarjaya, } \\
\text { Karang Tanjung, Sumur, Cibitung, Cikeusik } \\
\text { Cimanggu, TNUK }\end{array}$ & $8,946.6$ & $6,065.3$ & $15,011.9$ \\
\hline $\begin{array}{l}\text { Paddy field area (\%) } \\
\text { in Area III }\end{array}$ & & 59,6 & 40,4 & 100 \\
\hline $\begin{array}{l}\text { Total of Paddy - Field } \\
\text { Area (Hectares) }\end{array}$ & & $28,236.1$ & $15,414.3$ & $43,650.4$ \\
\hline
\end{tabular}




\section{SUSTAINABLE AGRICULTURAL FOODLANDS AREA MAP PANDEGLANG REGENCY}

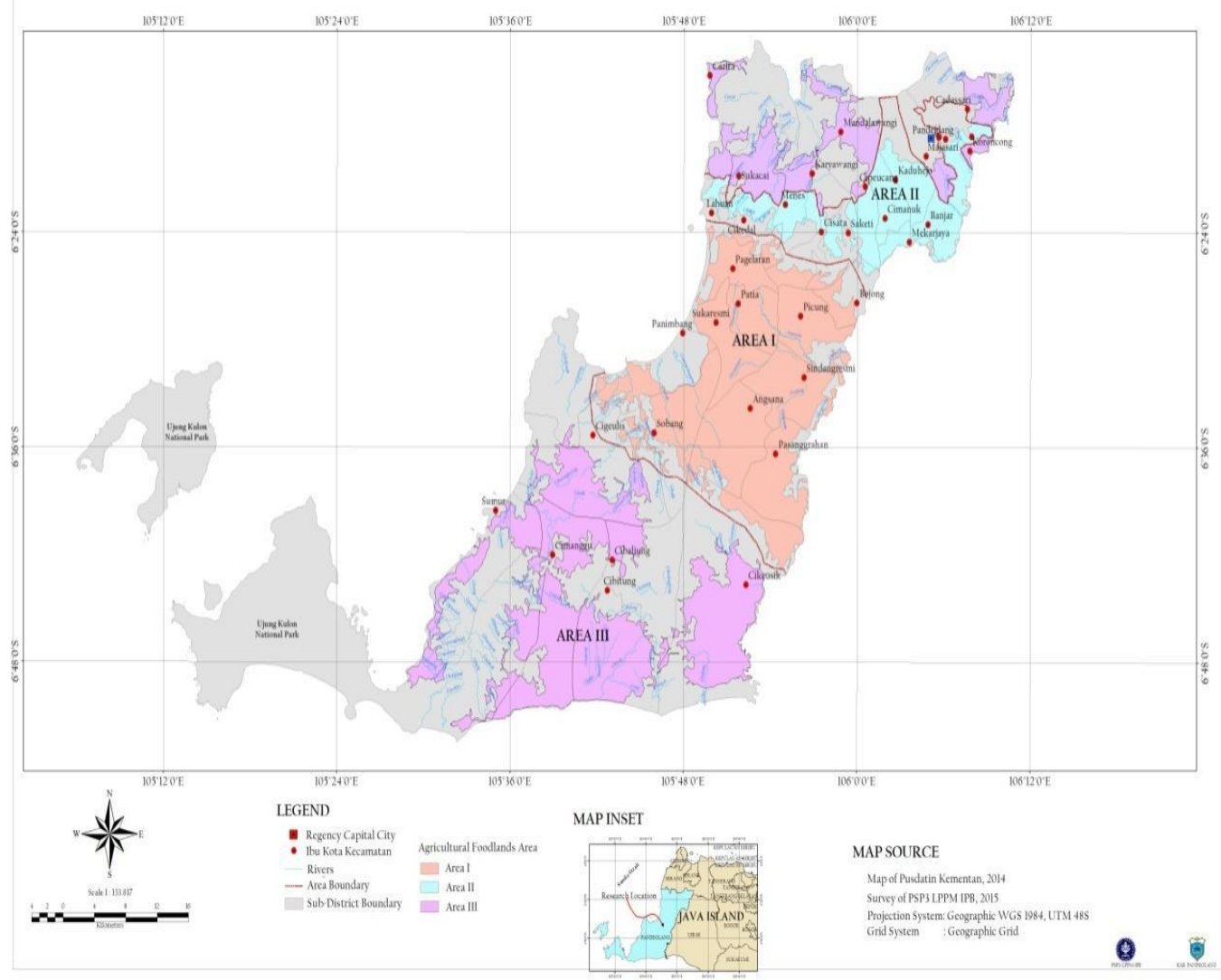

Fig. 1. Sustainable Agricultural Foodland Area Map, Pandeglang Regency

Besides having similarity characteristics on three areas, some differences of the peasant community were also found. Table 3 showed the peasant in Area II who are more developed than Area I and III. The age range of 40 to 70 in Area III is higher than two other areas. Likewise Area III is relatively has a lower level of education (Primary School). However, average of paddy-field area in Area III is more extent (1.1 hectares) than Area I ( 0.9 hectares) and Area II ( 0.7 hectares). This situation is similar with the description of paddy-field area in Area III. But there are the symptoms commercialization on paddy-field use that more frequently exist in Area I and III. It is indicated by the proportion of paddy-field that rented for the rentcultivation to other tenants in Area I and III are higher than Area II. On top of that, proportion of the peasants in Area III who are claim that their primary occupation as a peasant, had resulted the lower percentage points than other areas. This case in line with the peasant's perception who claimed about life sufficiency by farming activities, which those in Area II are depends their life into non-farming activities. Furthermore, many peasants household are tend to have no willingness orienting their children to become as a peasant. 


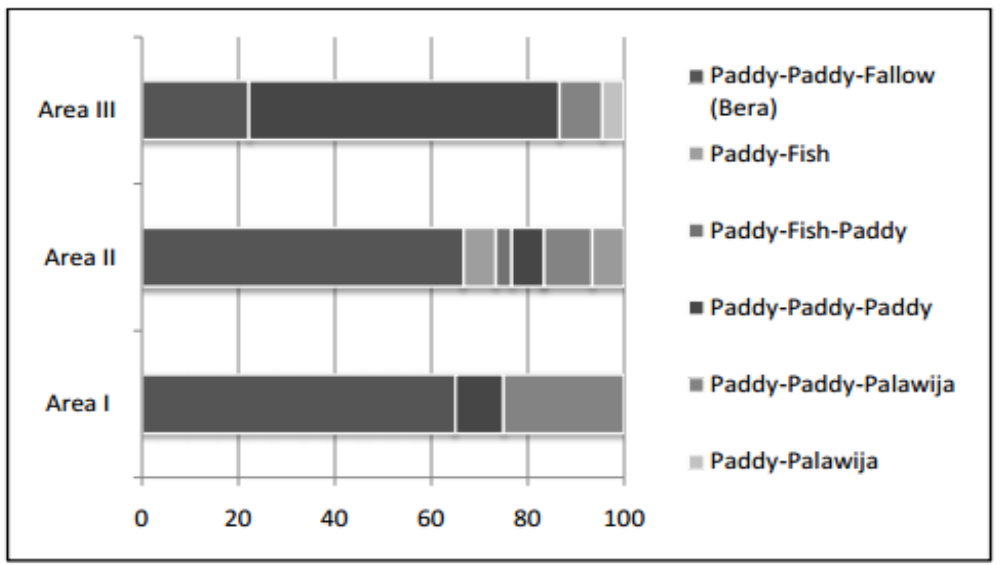

Fig. 2. Percentage of Peasant Based on Cropping pattern of Paddy-Field Use in Area I, II, III

According to the expert meeting about three Areas of paddy-field management and peasant condition as mentioned above, the policy at Regency level for paddy-field management on the three purposed areas about prevention of paddy-field conversion in the basis of protection and empowerment of peasantry is recommended. According to the Law No. 6 of 2014 on Rural, the empowerment of peasant community are should be implemented by two kinds of approaches. The first one is village-based development, namely as Village-Developing which focuses on the peasant as a rural society establishing the development on the rural scale. The second approach is Developing the Villages Area, where the peasant as a villagers are able to pursue the village government to establish inter-villages partnership by developing productive paddy-fields area in the unit of villages area. Interview result from correspondences and expert meeting discussion that held in Pandeglang Regency identified the strategic key factors either from internal or external ones. It had given significant effect on the prevention of paddy-field conversion. Schemes of stage priority factors, sub-factors, actors and review strategies determination are described in Fig. 3.

The strength internal key factors that had founded are: 1) Consciousness of peasantry about the existence and importance of the paddy-field (0.565); 2) Strong influential of local politician in Pandeglang Regency (0.262); 3) Work-ethic of paddyfield peasantries (0.118); and 4) Sufficiency on the paddy-fields area ( 0.055$)$. While, the key factors of weaknesses has identified based on the weight points of priorities are: 1) The lack access towards agro-industry of paddy field management $(0.571)$; 2) Peasant institutional has not optimized $(0.268) ; 3)$ The low of land-taxes causing the rural lands are liable to be owned by outsider (0.081); and 4) The lack information and technology on the paddy-fields management $(0.080)$. Results from expert meetings had also found the external factors about Opportunities and Threats from the successfulness of preventing paddy-field conversion. Four factors based on the weight points of priorities are : 1) High of demand towards Pandeglang rice production (0.523); 2) The degree supports from local government managing the paddy-fields $(0.263) ; 3$ ) The existence of Universities extension for sustainability of paddy-fields management (0.116); and 4) Policy of central government on obligations of sustainable agricultural land development $(0.099)$. While, the threat factors are : 1) The low of bargaining position of the peasant towards the grain buyer (0.560); 2 ) The high debt bondage system (0.249); 3) Price of rice policy that adverse the peasant (0.095); and 4) None of investment on paddy-field management (0.095).

Based on the result on prevention of paddy-field conversion workshop, strategic actor can be mapped based on weights of influential points, as follows : 1) Government of Pandeglang Regency (0.343); 2) Regional House of Representatives on Pandeglang Regency (0.194); 3) The peasants (0.142); 4) Villages government (0.100); 5) Universities (0.082); 6) NGO (0.051); 7) Private sectors (0.037); 8) Financial institution (0.026); and 9) Central Government (0.024). This finding showed that the prime movers that prevent paddy-field conversion are policy maker and executor of the policy (executive and legislative of government of Pandeglang Regency), peasants and villages government. Expert meeting which concerning about alternative strategy on matching stages, was appointed that 5 strategic points preventing the paddy-field conversion are: 1) Paddy-field Area Management is developed within inter-villages partnership; 2) Developing the Local Public Services Agencies for Protection of Paddy-field Peasantries which formed by Regency Government; 3) Inter-villages Rural Owned- 
Enterprises as a supporting unit for inter-villages partnership; 4) Increasing the number of agricultural facilities and infrastructures and local transportation in the units of Regency; and 5) Developing the progressive land-taxes for the landowner outside Regency.

The Local Public Services Agencies for Protection of Paddy-field Peasantries which formed by Regency Government as Badan Layanan Umum Daerah (BLUD), refer to Law No.25 of 2009 on Public Service which defined as BLUD. It is a local government agency that provides goods and services that are connected with the public. It must run a healthy business practices without prioritizing the quest for profit. It's a very special characteristic because government agencies are allowed to apply business practices as in common by the business / private. But although organized as a business institution, BLUD is not allowed to make a profit (not-for-profit). Their flexibility and autonomy in carrying out operations BLUD, namely: flexibility in terms of financial management, flexibility in the management of human resources and flexibility in terms of management and procurement of assets / goods. BLUD exempted from the provisions of the local government financial management in general.

Based on the results discussion from expert meeting, five priorities for prevention of paddy-fields conversion strategy had already arranged. First priority are, Developing the Local Public Services Agencies) in the units of Regency (BLUD Kabupaten) (0.457); Second, Paddy-field Area Management is developed within inter-villages partnership (0.262); Third, Rural Owned-Enterprises Inter Villages as the unit of management for the cooperation between the villages ( 0.121$)$; Fourth, Increasing the number of agricultural facilities and infrastructures and local transportation in the units of Regency (0.107); and Fifth, Developing the progressive land-taxes for the land owner outside the Regency $(0.054)$.

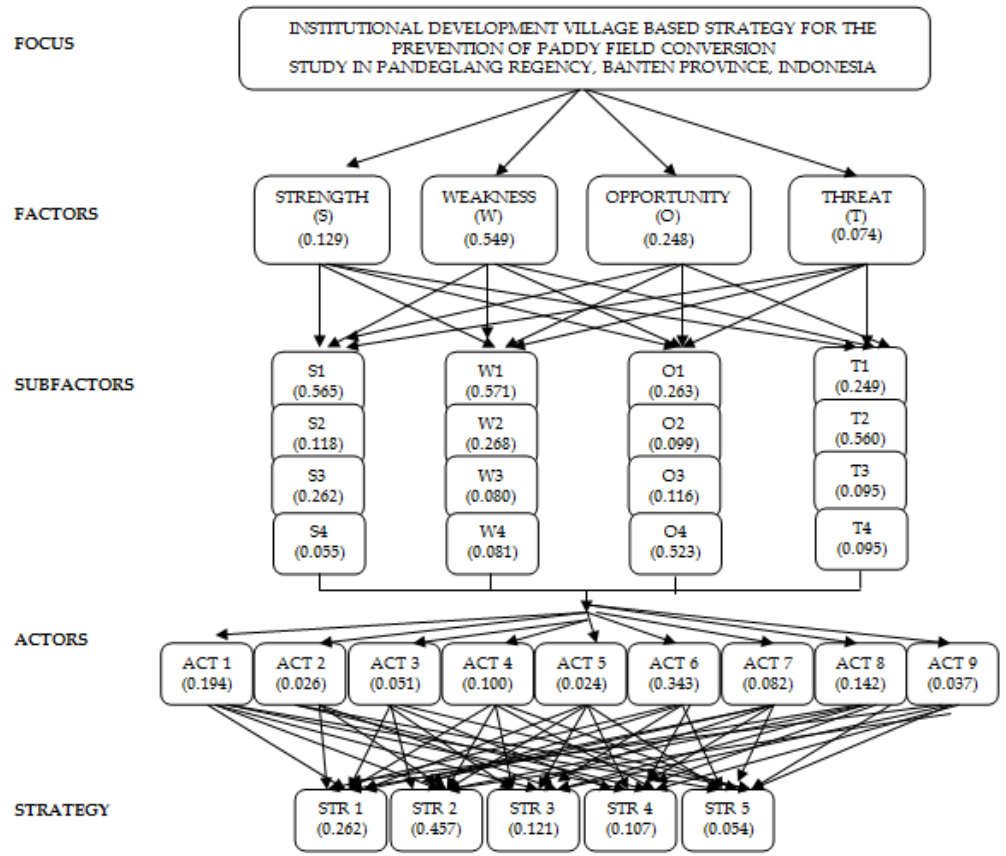

S1 = Consciousness of peasantry about the existence and importance $01=$ High demand on Pandeglang rice production of the paddy-field;

S2 = Strong influential of local politician in Pandeglang Regency S3 = Work-ethic of paddy-field peasantries; S4 = Sufficiency on the paddy-fields area

O2 = High supports from local government managing the paddy-fields

O3 = Existing of Universities extension for sustainability of paddy-fields management; O4 = Policy of central government on obligations of sustainable agricultural land development 


\begin{tabular}{|c|c|}
\hline $\begin{array}{l}\text { W1 = Lack access towards agro-industry of paddy field management); } \\
\text { W2 = Peasant institutional has not optimized } \\
\text { W3 = The low of land-taxes causing the rural lands are liable to be } \\
\text { owned by outsider; } \\
\text { W4= The lack information and technology on the paddy-fields } \\
\text { management }\end{array}$ & $\begin{array}{l}\text { T1 = Low bargaining position of the peasant with the grain } \\
\text { buyer } \\
\text { T2 = The high debt bondage system } \\
\text { T3 = Price of rice policy adverse the peasant } \\
\text { T4 = None of investment on paddy-field management }\end{array}$ \\
\hline $\begin{array}{l}\text { ACT1= Government of Pandeglang Regency } \\
\text { ACT2 = Regional House of Representatives on } \\
\text { Pandeglang Regency } \\
\text { ACT3= The peasants } \\
\text { ACT4= Villages government } \\
\text { ACT5 = Universities } \\
\text { ACT6= NGO } \\
\text { ACT7= Private sectors } \\
\text { ACT8= Financial institution } \\
\text { ACT9= Central Government }\end{array}$ & $\begin{array}{l}\text { STR1 =Paddy-field Area Management is developed } \\
\text { within inter-villages partnership } \\
\text { STR2= Developing the Local Public Services Agencies for } \\
\text { Protection of Paddy-field Peasantries which formed } \\
\text { by Regency Government } \\
\text { STR3= Inter-villages Rural Owned-Enterprises as a } \\
\text { supporting unit for inter-villages partnership } \\
\text { STR4= Increasing the number of agricultural facilities } \\
\text { and infrastructures and local transportation in the units of } \\
\text { Regency; } \\
\text { STR5= Developing the progressive land-taxes for the land }\end{array}$ \\
\hline
\end{tabular}

Fig. 3. Scheme of AHP-SWOT Analysis

The strength internal key factors that has founded are: 1) Consciousness of peasantry about the existence and importance of the paddy-field ( 0.565$)$; 2) Strong influential of local politician in Pandeglang Regency (0.262); 3) Work-ethic of paddyfield peasantries (0.118); and 4) Sufficiency on the paddy-fields area (0.055). While, the key weaknesses factors has identified based on the weight points of priorities are : 1) The lack access towards agro-industry of paddy field management (0.571); 2) Peasant institutional has not optimized (0.268); 3) The low of land-taxes causing the rural lands are liable to be owned by outsider (0.081); and 4) The lack information and technology on the paddy-fields management (0.080). Local Public Services Agencies (BLUD) of Protection, Welfare and Price Control for Cost of Goods Sold. By this role, BULD is able to maintain the stability of grains price which could beneficial for the peasant. Yet, this institution will become as a party assigning the paddy-field farming contract, or being as a partnership of farming contract, and as the information and technology service agency for the peasant. On the top of that, according to Law Number 19 of 2013 on Protection and empo werment of Farmers, BLUD also recommended three types of business models : 1) Manufacturers market limited operation, keeping the sold price on the peasant level which can guarantee the peasantry welfare; 2) Purchase contract on production on the first-period of planting should under warranty over the peasant's profit and reducing the risk of crop failure; and 3) Protection of rice commodities by peasant's shop or market to facilitate the consumers with the low of purchasing-power.

Mechanism of BULD Protection of Paddy-field Peasantry can be developed in Pandeglang Regency as shown at Fig 3. In this mechanism, developed institutional is a profitable supply change system and production for the shareholders. Proportion of benefit share that appointed from the expert meeting are: $34 \%$, for the peasant, $19 \%$ for the traders, $29 \%$ for Rice milling unit, $3 \%$ for polishing, $2 \%$ for transportation and $13 \%$ for the middleman outside the Regency. BULD is developed by the basis of paddy-field management on inter-villages partnership in the units of rural area. Development of rural area is conducted by participative approach, relevant with Law No.6 Year 2014 about Village. Paddy-field areas in the units of rural area are managed effectively and efficiently by Inter-Villages Owned-Enterprise (BUM Antar Desa). This kind of enterprise institution is a synchronizer that integrated with BLUD Protection of paddy-field Peasantry in Pandeglang Regency. This integrated cooperation affirms the path of information about peasants needs. It is started with the farming planning system, the problems and obstacles from cultivation toward post-harvest period. Besides that, information channel will be as media communication for asset and paddy-fields area infrastructure management in order to produce the rice with a good quality. One important thing which developed supporting the BLUD for Protection of Paddy-field Peasantry in Pandeglang Regency is the major support from central government to determine the land-taxes for the land-owner (residents) outside Pandeglang Regency. Other than that, determination for juridical instrument is a local regulation or Regents Regulation to support paddy-fields management by inter-villages partnership in the units of rural area. Those facilitations from Regency government are to manage the utilization of finances which derived from ABPN; APBD, APBD of Village and other financial institutions from certainparties.

Fig. 4. BLUD (Local Public Services Agencies) for Protection of Paddy-fields Peasantry 


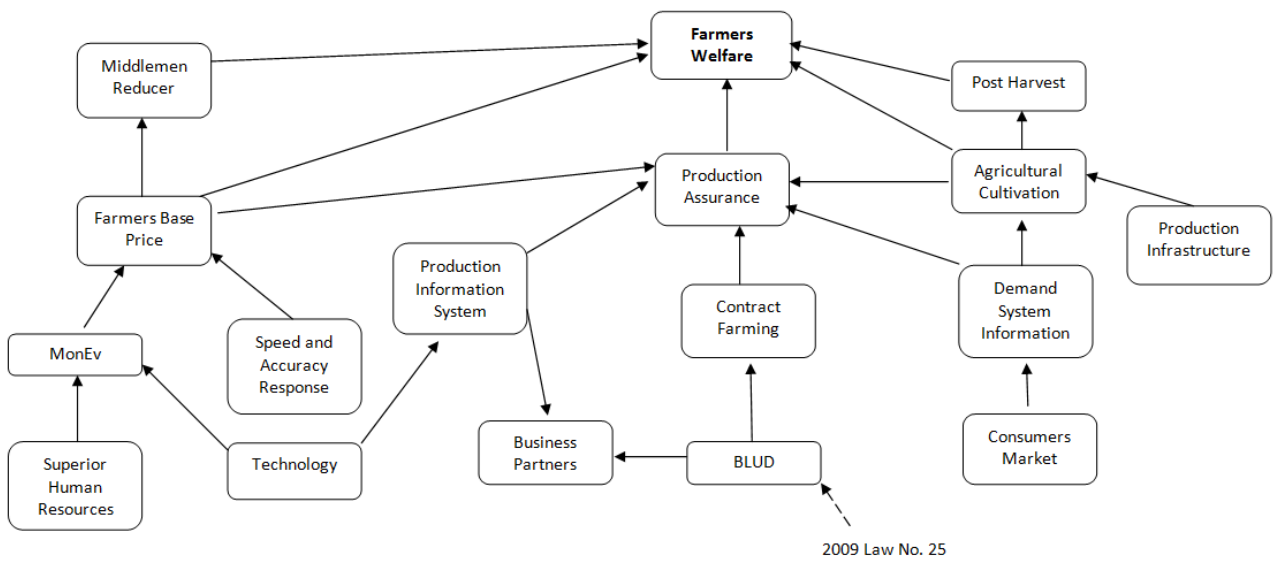

Strategic priority results then synchronized with the medium-term objectives ( 5 years). This would be as the time-frame for institutional development village-based strategy for the prevention of paddy-field conversion. Three considerable stages for 5 years are : 1) Capacity Development of Peasant Group and Establishment of Villages partnership institution; 2) Institutional Development of Paddy-Field Peasantry; 3) Protecting and Empowering of Peasantry within Industrial Partnership (Fig. 5).

It has shown on establishment of BLUD that will take 1-2 years period. This activity started by development of peasant group and establishing inter-villages partnership institution managing paddy-field area to raise its productivity. Following the function of BLUD as shown on figure 5, BLUD will be developed by creative cooperation between other parties such as business institution, academician, finance institution during 2 two years. This stage will pursuing BLUD become as an institution so-called Local Public Service Agency Protection and Empowerment of The Peasant. During 1-3 years, besides protecting from land conversion, it also will develop the paddy-field peasantry by implementing a conducive industrial partnership.

Fig. 5. Time frame of institutional development village-based strategy for the prevention of paddy-field conversion

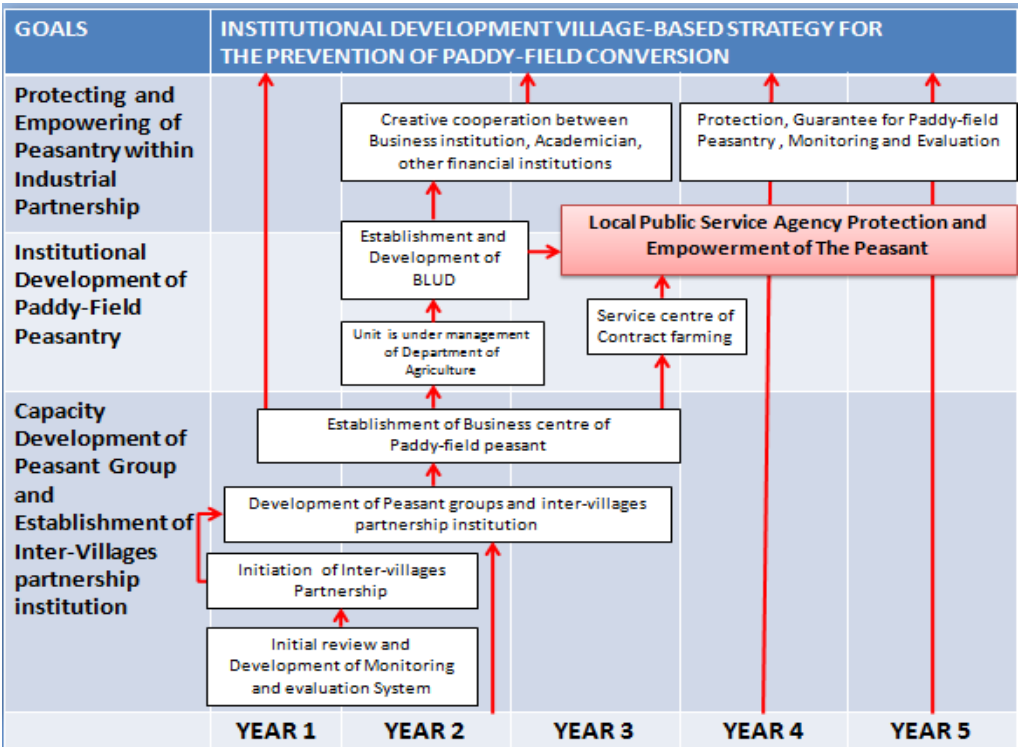




\section{CONCLUSIONS AND POLICY IMPLICATION}

Conclusion of this research is the prevention of paddy-field conversion particularly in Pandeglang Regency by the establishment of the Local Public Service Agency (BLUD) as the village-based strategy to protect the peasantry of paddyfield farming. Thus, it expected to become as a synchronizer among the shareholders which consist of peasant community, village government, the third-party in the farming management, regency government until province and central government.

Implication from those above, the role of government in the prevention of paddy-field conversion needs to use the various development approaches. This approach is either by the top-down and the bottom- up approach. Moreover, technocratic which underlying with technology for the paddy-field management and enterprise need to be affirmed by participative development approach. It should involve multi-parties who have a common interest about institutional village-based development in order to prevent the paddy-field conversion.

\section{ACKNOWLEDGEMENT}

I am grateful to Ir. Wowon Dirman, MM, Head of Department of Agriculture and Livestock Office of Pandeglang Regency for the financial funding to do this research. I am also indebted to Dr. Baba Barus, M.Sc, expert of regional mapping, who has helped me in the paddy field re-mapping process. Finally, I would like to express my sincere gratitude to two anonymous reviewers for their invaluable comments, which led to significant improvements of the manuscript.

\section{REFERENCES}

[1] Allen, T.H. 1978. Policy Sciences and Structures Research Praeger Pwd. New York.

[2] Arnold, Edward. 2005. Political Ecology: Where is the Ecology. Progress in Human Geography. 29(1):73 - 82. Badan Pusat Statistik ( BPS). 2009. Survei Pertanian : Luas Lahan Menurut Penggunaannya di Indonesia. Badan Pusat Statistik. Jakarta, Indonesia.

[3] Bernard, Ronald et al. 2014. Assesment Of Information Needs Of Rice Farmers In Tanzania; A Case Study Of Kilombero District, Morogoro. Library Philosophy And Practice (E-Journal) University Of Nebraska - Lincoln. 2014. Tanzania.

[4] Bidhendi, GRN. 2005. Application od ozonation in drinking water disinfection based on an environmental management strategy approach using SWOT method. Environ, Health, Sci, Eng Journal, 3(1) 23-30.

[5] Carambas, et al. 2015. Decomposition of the Effect of Small Scale Irrigation System On Outputs of Selected Lowland and Upland Rice in the Phillipines. Journal ISSAAS Vol. 21, No. 175-189.

[6] Direktorat Jenderal Perkebunan. Kementerian Pertanian. 2014. Pertumbuhan Areal Kelapa Sawit Meningkat. Ditjenbun.Pertanian.Go.Id/Berita.

[7] Eriyatno 2007. Riset Kebijakan Metode Penelitian Untuk Pascasarjana. IPB Press: Bogor.

[8] Erizal Jamal, Syahyuti, Aten M. Harun. 2002. Reforma Agraria dan Masa Depan Pertanian. Jurnal Litbang

[9] Fuer, HN. 2008. Sustainable Agricultural Techniques And Performance Oriented Empowerment. An Actor Network Theory Approach To Cedac Agricultural And Empowerment Programmes In Cambodia. Master Thesis, Queen Elizabeth House, St. Anthony's Collage University Of Oxford. 2008. Cambodia.

[10] Greenberg, B. James and Park, K. Thomas, 1994, Political Ecology, Journal of Political Ecology Vol. 11994.

[11] Irawan, Bambang. 2005. Kebijakan Pengendalian Alih Fungsi Tanah Pertanian dan Implementasinya. Forum Penelitian Agro Ekonomi. 23 (1): 1-18.

[12] Kahraman, C., A. Beskese., F.T. Bozbura, 2007. Prioritization of e-Government strategies using a SWOT- AHP analysis: the case of Turkey. European Journal of Information System, 16 (1) : 284-298

[13] Kedi Suriadisastra dan Nana Sutrisna. 2011. Membangun Kemampuan Pengelolaan Daerah Otonom. Dalam Membangun Kemampuan Pengelolaan Lahan Pertanian Pangan Berkelanjutan. Badan Penelitian dan Pengembangan Pertanian. Kementerian Pertanian. Hal 245-266. 
[14] Kolopaking, L.M. 2000, International Labor Migration and the Development of the Sending Region in Java. Ph.D. Thesis. University Science Malaysia, Penang.

[15] Kolopaking, L.M. 2008. Pengembangan Kawasan Perdesaan Berbasis Komunitas. Departemen Komunikasi dan Pengembangan Masyarakat. Bogor: PSP3-IPB dan Ditjen PMD Depdgari.

[16] Law No. 23/2014 of the Republic of Indonesia on Local Government

[17] Law No. 6/2014 of the Republic of Indonesian Village.

[18] Law No.19/2003 of the Republic of Indonesia on Protection and Empowerment For Peasantry. Law No.25/2009 of the Republic of Indonesia on Public Service.

[19] Law No.41/2009 of the Republic of Indonesia on Protection of Sustainable Food Farmland. Moleong, Lexy J. 1991, Metedologi Penelitian Kualitatif, PT Remaja Rosdakarya, Bandung.

[20] Nyak Ilham, Yusman Syaukat, Supena Friyatno. 2005. Perkembangan dan faktor-faktor yang mempengaruhi konversi lahan sawah sertadampak ekonominya. Jurnal Universitas Udayana. 5(2).

[21] Pertanian. 21(4):133-139.

[22] Pusat Data dan Sistem Informasi Pertanian Kementerian Pertanian. 2013. Buletin PDB Sektor Pertanian Volume 12 (1). Jakarta.

[23] Pusat Data dan Sistem Informasi Pertanian Kementerian Pertanian. 2014. Statistik Ketenagakerjaan Sektor Pertanian Tahun 2014. Jakarta.

[24] Putra, RN. 2015. Implementasi kebijakan pengendalian alih fungsi lahan pertanian di kota batu sebagai kawasan agropolitan. Kebijakan dan Manajemen Publik Vol 3 (2), Mei-Agustus 2015. Indonesia.

[25] Saaty, T. L. 1991. Pengambilan Keputusan Bagi Para Pemimpin, Proses Hirarki Analitik Untuk Pengambilan Keputusan dalam Situasi yang Kompleks. Pustaka Binama Pressindo.

[26] Suradisastra, Kedi 2011. Membangun Kemampuan Pengelolaan Lahan Daerah Otonom. Halaman 244-256. Dalam Kedi Suradisastra et al., Membangun Kemampuan Pengelolaan Lahan Pertanian Pangan Berkelanjutan.. Badan Penelitian dan Pengembangan Pertanian Kementerian Pertanian dan IPB Press. Jakarta.

[27] Susanti, et al. 2015. CO2 and CH4 Emission on Different Water Management and Pesticide Treatments In Rice Fields of Tidal Peat Swamp. Journal ISSAAS Vol. 21, No. 2: 86-103.

[28] Syahyuti, 2011. Efektivitas Land Reform dalam meningkatkan Akses terhadap Lahan. Halaman 197-219. Dalam Kedi Suradisastra et.al (eds.), Membangun Kemampuan Pengelolaan Lahan Pertanian Pangan Berkelanjutan.. Badan Penelitian dan Pengembangan Pertanian Kementerian Pertanian dan IPB Press. Jakarta.

[29] Wahyunto, Yoyo Soelaeman, Sunaryo. 2004. Gagasan pengendalian konversi lahan sawah dalam rangka peningkatan ketahanan pangan nasional [prosiding]. Seminar Multifungsi Pertanian dan Konservasi Sumberdaya Lahan.

[30] Xie, Yichun et al. 2005. Socio-economic driving forces of arable land conversion: a case study of Wuxian city of China. Global Environmental Change 15:238-252. 